\title{
はすば歯車対のかみあいはずれ側における潤滑油流れの水中模擬実験*
}

\author{
大嶋 俊一 ${ }^{* 1}$, 松村 茂樹 ${ }^{* 1}$, 北條 春夫 ${ }^{* 2}$
}

\section{Experimental Study of the Lubricant Flow around the Mesh-Ending Region Simulated in Water Using a Helical Gear Pair}

\author{
Shun-ichi OHSHIMA ${ }^{* 1}$, Shigeki MATSUMURA and Haruo HOUJOH \\ ${ }^{* 1}$ Precision and Intelligence Laboratory, Tokyo Institute of Techonology \\ 4259 Nagatsuta-cho, Midori-ku Yokohama, 226-8503 Japan
}

\begin{abstract}
The purpose of this study is to investigate the 3-D flow of lubricants around the mesh-ending region of a rotating helical gear pair. It has been revealed that there are air-flows around the meshing region, so effective lubrication should be considered with the flow, especially in severe condition of the transmission by gears, such as a high circumferential velocity or wider tooth width. In this paper, a simulating experiment is introduced, in which an acrylic helical gear pair is immersed into the water, and driven. This experiment makes phenomena slower than actual lubrication in the air, so observations become easier. Stainless particles are injected into the mesh-ending region like lubricants against meshing direction, and suspended sparsely in the water. The motions of the particles are captured by a high-speed camera. The camera is located to be able to look into the space between the teeth. Optical astigmatism is introduced intentionally into the system for the observation with the high-speed camera. With this optical system, distorted elliptic images of the particles are observed when the particles are out of focus. Numerical procedure is investigated to evaluate the positions of the particles along the optical axis from the distorted particle image. The tracings of the particles injected from various nozzle positions are shown in this paper, and hitting locations of the particles on the tooth surfaces are found out as lubricated region.
\end{abstract}

Key Words : Gear, Lubrication, Flow Visualization, High-Speed Camera, Tracer, Optical Astigmatism

\section{1. 緒論}

歯車対の運転には潤滑が不可欠であり，潤滑系になんらかの問題がある場合，耐久性などに多大な影響を及ぼ す. 特に, 歯車の回転数が高く径が大きいことに伴う高周速や，高トルクといった過酷な運転条件下では，かみ あいに伴う歯面の発熱が顕著となって歯面損傷の原因となるため，特にかみあい直後の歯面を潤滑によって十分 に冷却することが重要である，歯車が高周速で運転される際は，かみあいはずれ側に供給された潤滑油が，歯面 に付着して冷却するという目的を果たすことなく歯車の円周外に飛ばされることを勘案し, 過剩な潤滑油が ジェット噴霧により供給される場合がある. しかし，効率的な供給が行えているかは未だ不明である.

歯車周りに生じる空気流の泠却効果に着目した研究として, PTV法によって歯車周辺の空気流の速度ベクトル 分布を計測した研究 ${ }^{(1)}$ がある。 一方, 潤滑方法については, 高負荷減速装置の遊星歯車装置内部の潤滑油流れを 可視化して油浴潤滑のかくはん状況を検討した研究(2)がある. また, 油浴潤滑時の飛沫挙動が実験と解析結果で

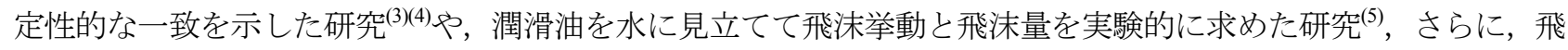
沫量の計測から潤滑油飛沫の有効付着率を実験式として示した研究(6)がある.また，強制潤滑に関しては，かみ あい部へ潤滑油を噴射することで実験的に潤滑油挙動を把握した研究 ${ }^{(7)(8)}$ がある. しかし, これらの多くの研究で

* 原稿受付 2011 年 11 月 9 日

*1 正員, 東京工業大学 精密工学研究所（干226-8503 神奈川県横浜市緑区長津田町 4259）

*2 正員, フェロー, 東京工業大学 精密工学研究所

E-mail: ohshima@pi.titech.ac.jp 
対象としているのは平歯車であり，広く一般的に用いられているはすば歯車を対象とした，歯車周辺の空気流や 潤滑油挙動に関する研究は見受けられない.

著者らは，まず平歯車についてかみあい部周辺における空気流を実験的に把握し，かみ合っている歯車の歯溝 が形成する空隙が, かみあいの進行に伴ってその体積が刻々と変化することで, 内部の空気が排出されたり, 逆 に外部の空気が吸引されたりする様子を明らかにしてきた ${ }^{(9)}$.それらのかみあい部周辺の空気流が，かみあい部 周辺に供給された潤滑油の供給を助けたり邪魔したりすることが予想される.さらに，歯溝内に空気が吸入され るのは，空隙体積がかみあいの進行に伴って増加する，かみあい終わり側の挙動である．冒頭に述べた歯面冷却 をねらった潤滑においては，潤滑油が歯溝内に吸引されるような効果が期待できる．よって，かみあいはずれ側 周辺の空気流挙動や，それが潤滑油供給に及ぼす影響を把握することは，効率的な潤滑手法を導入する際に重要 な知見となり得る.

さらに，は寸ば歯車のかみあい部周辺の空気流を把握するために，鉄とナイロンの歯車を組み合わせて無潤滑 で運転し，スモークワイヤー法によってかみあい部周辺の空気流を可視化したり ${ }^{(10)}$, 潤滑油を着色してソレノイ ドを用いた装置で油滴として射出し，その軌跡を可視化しようとしたりした ${ }^{(11)}$.しかし，撮影に用いた毎秒1000 フレームの高速度カメラでも, 歯車かみ女い部において周速 $50 \mathrm{~m} / \mathrm{s}$ に達寸る高速な現象を的確に捉えることは困 難であった，その上，最も観察したい領域である歯車かみあい部の歯溝内部を，高速度力メラを用いた撮影に必 要な十分な光量の下で観察することは極めて困難であった.

そこで本研究では, 試験用はすば歯車対を水中で運転する実験手法を試みた ${ }^{(12)}$ 。この手法によって, かみあい 部周辺の空気流れを水の流れに置き換え, より遅い挙動として観察寸ることができる. これにより, 高速度カメ ラのフレームレートやシャッタースピードを遅くすることができ, 照明の条件を緩和することができる. また, 水の流れを可視化する懸濁粒子として，比重の大きな金属粒子を用いることとし，空気中の潤滑油滴と見立てら れるような実験を行った，本論文は，その潤滑油滴と見立てた金属粒子の運動挙動を観察して，歯面に到達する までの軌跡を取りまとめ，は寸ば歯車対のかみあい終わり領域における潤滑油挙動を考察した結果を示す.

\section{2. 実験装置}

\section{$2 \cdot 1$ 水槽}

実験に用いた水槽の外観を図1に示す，水槽の大きさは，歯車の回転軸と並行な方向に $550 \mathrm{~mm}$ ，軸に垂直な方 向に $750 \mathrm{~mm}$ の底面を有し，深さは940mmである．はすば歯車の駆動軸と被動軸は，水槽外部においてそれぞれ2 箇所で玉軸受によって支持される片持ちの軸とし，シールを介して水槽内に挿入されている. 駆動軸は, 水槽外 部のモータによって駆動され, 被動軸の水槽外部の端部には, なにも接続されていない，運転中は，シール部の 回転方向の抵抗や，は寸ば歯車が水を攪拌する抵抗のため, 歯面分離が起こっていないことを確認した.

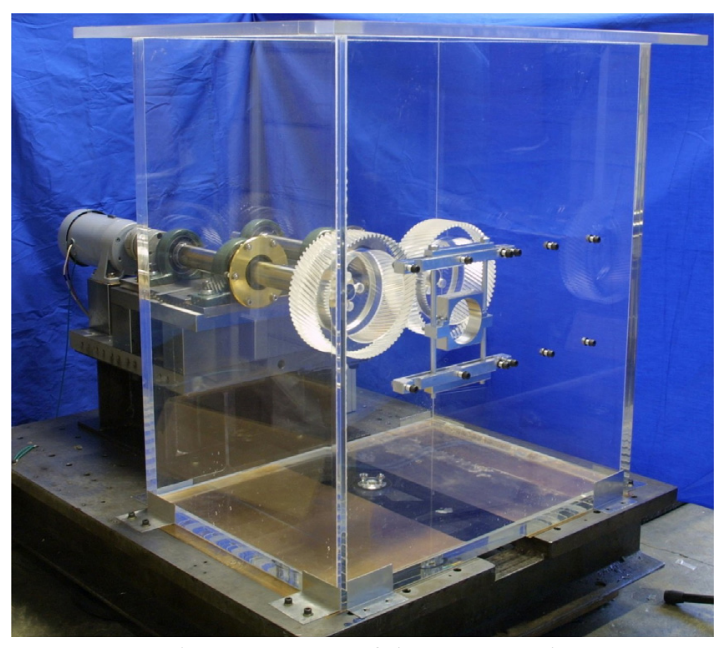

Fig. 1 Image of the water tank
Table 1 Specifications of the gear pair

\begin{tabular}{lcc}
\hline Helix angle & {$[\mathrm{deg}]$} & 29.72 \\
\hline Number of teeth & & 66 \\
\hline Normal pressure angle & {$[\mathrm{deg}]$} & 20 \\
\hline Normal module & & 3 \\
\hline Face width & {$[\mathrm{mm}]$} & 75 \\
\hline Nominal center distance & {$[\mathrm{mm}]$} & 228 \\
\hline Coefficient of tangential shift & & 0.25 \\
\hline Material & & PMMA \\
\hline
\end{tabular}




\section{$2 \cdot 2$ 試験用はすば歯車対}

本実験に用いたは寸ば歯車対の諸元を表1に示寸，歯数比は1で，透明なアクリル樹脂（PMMA）を用いてホブ 切りで製作した。 なお，歯面粗さは本研究で着目している流れに影響しないとして，仕上げに特段の注意を払っ ていない.この歯車は透明であるため, 流れの挙動を観察したい歯車かみあい部の領域に光が透過して影になり にくい. すなわち，撮影領域の明るさが確保でき，高速度カメラを用いた撮影に有利である.

本実験では, この歯車対を前述の水槽中で, 40rpmあるいは120rpmで運転した. 歯車の周速はそれぞれ $0.48 \mathrm{~m} / \mathrm{s}$, $1.43 \mathrm{~m} / \mathrm{s}$ となる．著者らが行ったかつての実験では，直径が $300 \mathrm{~mm}$ の歯車対を空気中で運転していた(9)(10)(11). 周 速を代表速度とし, 直径を代表寸法として計算される回転レイノルズ数を基に, レイノルズの相似則を適用させ れば，空気と水の動粘度は約15倍異なるので，水中実験においては歯車の回転数を $1 / 15$ にできる．ただし，本実 験の歯車径は, 前述の空気中の実験条件に対して $3 / 4$ であるので, 水中実験の回転数は $1 / 8.4$ となる. よって, 本 実験の結果を前述の空気中の実験と比較する場合，それぞれ340rpm，1020rpmに相当する.

\section{3. 可視化手法}

\section{$3 \cdot 1$ 懸濁粒子}

本実験では，入手可能な金属球である直径 $0.5 \mathrm{~mm}$ のステンレス球を懸濁粒子として用いた．ステンレスの比重 は8.0であり，空気中に供給された潤滑油滴を模することを想定した.

ステンレス粒子は，つや消し白に塗装して光を反射させ，懸濁粒子の外形が正確に撮影されるようにし，輪郭 形状を正しく捉えられるようにしている.

\section{$3 \cdot 2$ 高速度カメラと光学系}

本実験における粒子軌跡の撮影は，高速度カメラ（フォトロン社製 FASTCAM MAX 120K）を用い，フレーム レートを2000fpsとした。レンズは，Nikkor ED 180mm F2.8に，接写リング typeK1: 6mm, E2: 14mm, M: 27mm を 組み合わせて用い, 絞りはF4.0とした.

水槽と高速度カメラの設置位置関係を図2に示寸. 高速度カメラの光軸は, はすば歯車のかみあい部において歯 溝内部が観察できるように，は寸ば歯車のねじれ角と平行になるように傾けて設置した. 2台のメタルハライドラ イト（フォトロン社製 HVC-SL）をカメラの両脇に設置して，水槽外から撮影領域を照らした．さらに光軸上の 背景には, 水中に鏡を設置し, 水槽壁面には外部から灰色紙を貼り付けてあり, ライトの光を背後から反射させ て撮影領域全体が明るく見えるように，これらの配置を試行錯誤的に決定した. 図2から明らかなように，高速度 カメラの光軸と水槽外壁が垂直でないために生ずる光の屈折を避けるために, 水槽壁の両面にアクリル製のプリ ズムを取り付けた. さらに, 水槽外部のプリズムの高速度カメラ側端面は, 円筒レンズとして機能するように, 曲率半径 $13 \mathrm{~m}$ の筒面を成型加工してある.これは, 本観察実験において, 懸濁粒子の光軸方向に沿った移動を 推定し, 結果的に懸濁粒子の三次元軌跡を単一の高速度カメラで把握しようとするための光学系である. その原 理を次節で述べる.

\section{$3 \cdot 3$ 光軸方向位置推定法の原理}

本実験では，高速度カメラで水槽内のステンレス粒子を観察する際に，レンズのフォーカスリングをあらかじ め固定しておく，水槽内の粒子が光軸と垂直なある平面上に存在するときに，円筒レンズを通して撮影された粒 子像が球となる. 本手法では，その平面を基準面と呼ぶことにする．一方，粒子が基準面以外の平面上にあると き，撮影された粒子像がぼける，そのとき，水槽外壁に取り付けられている円筒レンズの効果で, 円筒レンズの 円筒軸線方向とそれに垂直な方向で焦点距離が異なるために非点収差が発生寸る．それにより，粒子位置が基準 面の手前側か遠方側かによって, 球状のステンレス粒子像の歪み方が異なって観察される.

図3は, 本実験の光学系によって実際に得られた粒子像と, そのときの基準面に対する粒子の相対的な位置関係 を模式的に表した図である，粒子が基準面の手前側に存在する場合には，ぼけた像は，円筒レンズの円筒軸線と 平行に長い軸を有する楕円形に歪む. 粒子が基準面より遠方にある場合は, 楕円の長軸と短軸が入れ替わる.こ の光学的な現象は, 光ディスクのピックアップレンズにおけるフォーカシングに応用されてよく知られている. 


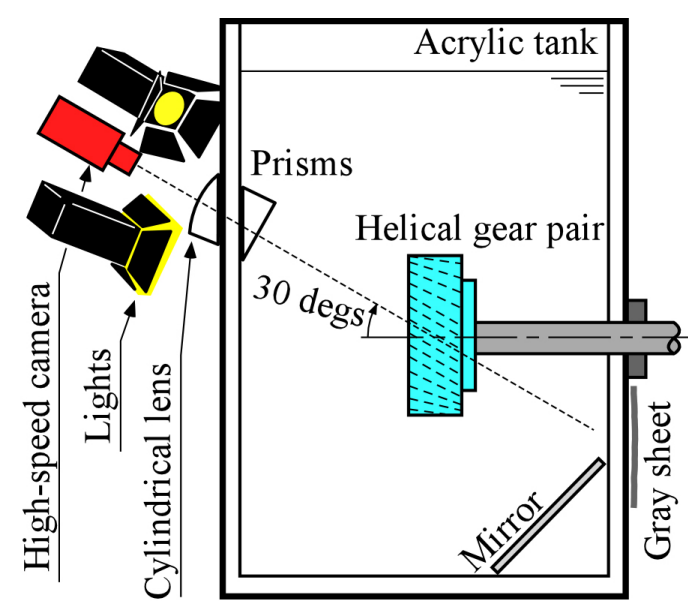

Fig. 2 Experimental layout

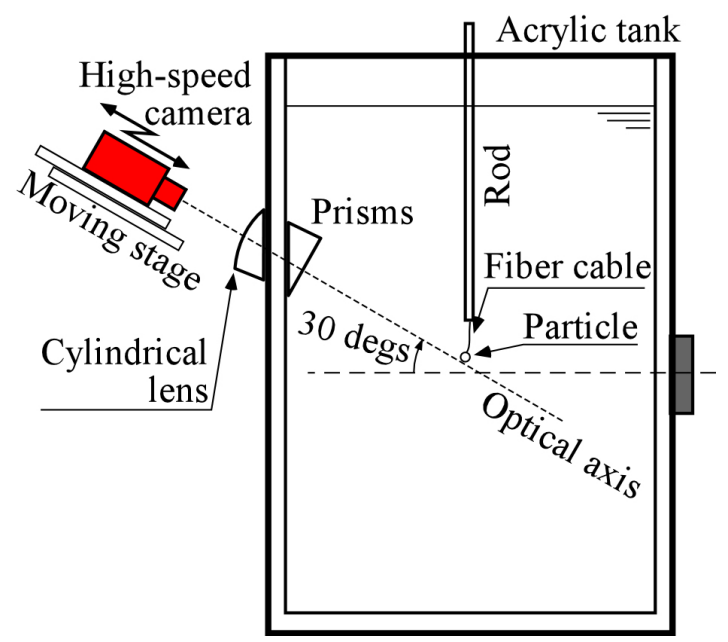

Fig. 4 Layout for the calibration

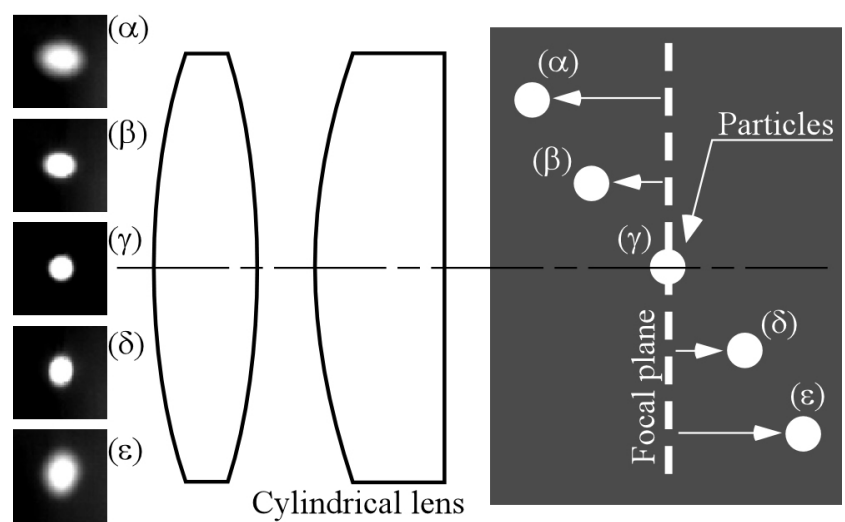

Captured images

Fig. 3 Principle for the 3-D localization of the particle with the cylindrical lens
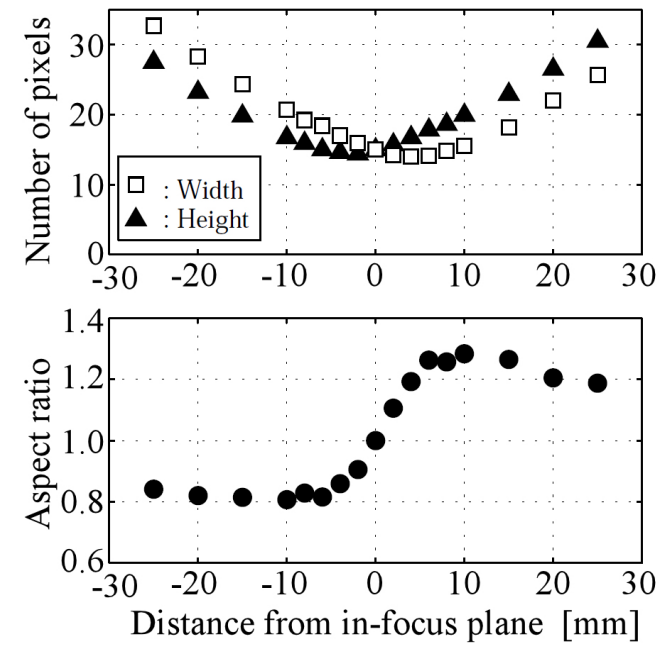

Fig. 5 Variations of the image sizes of the particle

本研究では, 円筒レンズを組み込んだ光学系を通して撮影した水中の粒子像の歪み方から, 基準面からの相対 的な光軸方向位置を画像処理によって推定する方法を提案する. すなわち，水中に懸濁した粒子の三次元的な位 置を，一方向からの観察によって把握することができる.

\section{$3 \cdot 4$ 校正実験}

本研究で提案する粒子の光軸方向位置の推定法を適用するために, 円筒レンズを含んだ光学系によって歪んだ 画像と，基準面位置を基準とした粒子の相対的な位置の関係を校正した. 図4は，その校正実験のレイアウトを示 している. 図2に示した装置から水中のはすば歯車対を撤去し，1個のステンレス粒子を，水中のはすば歯車かみ あい部に相当する位置付近に固定した. 水中における光学系の基準面位置は, カメラ三脚の雲台に取り付けたス ライドテーブルによって変化させた. なお, カメラレンズのフォーカスリングは動かないように固定してあり, 基準面位置はレンズからおおむね $1 \mathrm{~m}$ である. 水槽外壁面に取り付けてあるプリズムの円筒レンズ面を通して粒子 像を静止画像として撮影し, 楕円形状に歪んだ像の長軸, 短軸の長さを画像処理によってピクセル数として取得 した．なお，楕円形に歪んだ像は，粒子位置が基準面からずれていることによるものであるから，境界線がぼけ ている，楕円の長短軸長を決定するためのエッジ判定は, 取得画像全体の明るさを正規化した上で, 経験的に定 めたしきい值に従っている.

校正実験の結果を図5に示す．この図には，基準面位置を零とした相対的な粒子位置を横軸とし，撮影された楕 円形の長軸と短軸の変化を縦軸にしたグラフと, 楕円形の長短軸比の変化を縦軸にしたグラフをそれぞれ示して いる. なお，横軸の正は粒子が基準面よりも遠くにあることを示寸. 図5下側の長短軸比のグラフより，基準面位 置前後の $\pm 5 \mathrm{~mm}$ の範囲では, 歪んだ楕円形の長短軸比が直線的に変化している一方で, その外側の領域では, 有 
意な変化が認められないことがわかる.また，長短軸長を縦軸とした図5上側のグラフでは, 基準面から離れるに 従い，長軸と短軸の長さが単調に伸びていることがわかる．すなわち，基準面付近では円筒レンズの効果による 粒子像の長短軸比変化が有意である一方で, 基準面から $10 \mathrm{~mm}$ 以上離れた領域では, 粒子像のエッジがぼけるこ とによる単純な拡大傾向が有意であると考えることができる．その際，楕円形の長短軸の方向によって粒子が基 準面のどちら側に存在するかが判断できる.

よって, 本手法では, 水中のステンレス粒子を撮影し, 前述の光学系によって楕円形に歪んだ粒子像の長軸, 短軸の長さを画像処理によって得て, 図5に示した校正曲線を参照して光軸方向の相対的な粒子位置を推定した. 図5のいずれのプロットを参照するかは, 楕円形に歪んだ粒子像の長軸が一定值を下回る場合は長短軸比とし, そ れ以上の場合は長短軸長の拡大とした. 本手法で求められる光軸方向の位置は, 基準面位置を基準としておおむ ね土 $25 \mathrm{~mm}$ である. 一方, 試験用歯車対の歯幅は $75 \mathrm{~mm}$ である. 本手法を用いて, 水中のはすば歯車対のかみあい 部を流れる懸濁粒子の三次元軌跡を求める際は, 歯幅全体に渡って流れ挙動を把握するために, カメラ三脚の雲 台部に取り付けたスライドテーブルを用い, 観察する領域に合わせて基準面位置を歯幅全体に渡って移動させた.

\section{4. 実験方法}

\section{$4 \cdot 1$ 座標軸の定義}

水中に懸濁したステンレス粒子の三次元軌跡を表示する際, 三次元空間の座標系を図6のように定義する. 原点 は, ピッチ点と, はすば歯車のかみあい始め側端面の交点とする， $x$ 軸は，歯車の両軸と垂直に交わり，駆動側 歯車から被動側に向から方向を正とする，y軸は歯車軸に平行で, はすば歯車のかみあい始め側端面から終わり 側端面に向から方向を正とする. $z$ 軸は図6において鉛直方向であり, かみあいが進行する方向を正とする.

本論文における粒子の三次元軌跡の表示は，歯車を $y$ 軸に沿って正の方向を見る図6左側のような $x-y$ 平面に 投影した図と， $x$ 軸の負の方向を見る図6右側のような $y-z$ 平面に投影した図に分けて表示する. なお，図6右側 に示した $y-z$ 平面上の描画に関しては, 駆動歯車と被動歯車に囲まれたかみあい直後の空間であり, 本論文で提 案している，円筒レンズを用いた光軸方向の粒子位置推定法の導入によって，はじめて観察が可能となる.

\section{$4 \cdot 2$ 懸濁粒子の供給方法}

粒子を供給するノズルは，内径 $2 \mathrm{~mm}$ で外径 $4 \mathrm{~mm}$ のポリプロピレン製チューブであり， $z$ 軸の正の領域であるか みあいはずれ側で図6のように鉛直下向きに設置した，ノズル位置は $x=0 \mathrm{~mm}$, ピッチ点からの高さを $z=50 \mathrm{~mm}$ と一定とし, $y$ 軸方向に変化させた.

ノズルの他端には, 内径 $0.56 \mathrm{~mm}$ のテフロンチューブを介してシリンジが接続してある. 観察実験前に, ステン レス粒子をチューブ内に一列に配列させておき, シリンジには水を満たした. シリンジのピストンを直動機構の モータによって一定の速度で押し出し，チューブ内の粒子を水と一緒にノズルから射出し，かみあい点に向かっ

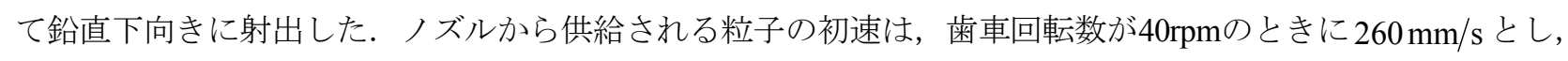
$120 \mathrm{rpm}$ ときに $365 \mathrm{~mm} / \mathrm{s}$ とした.
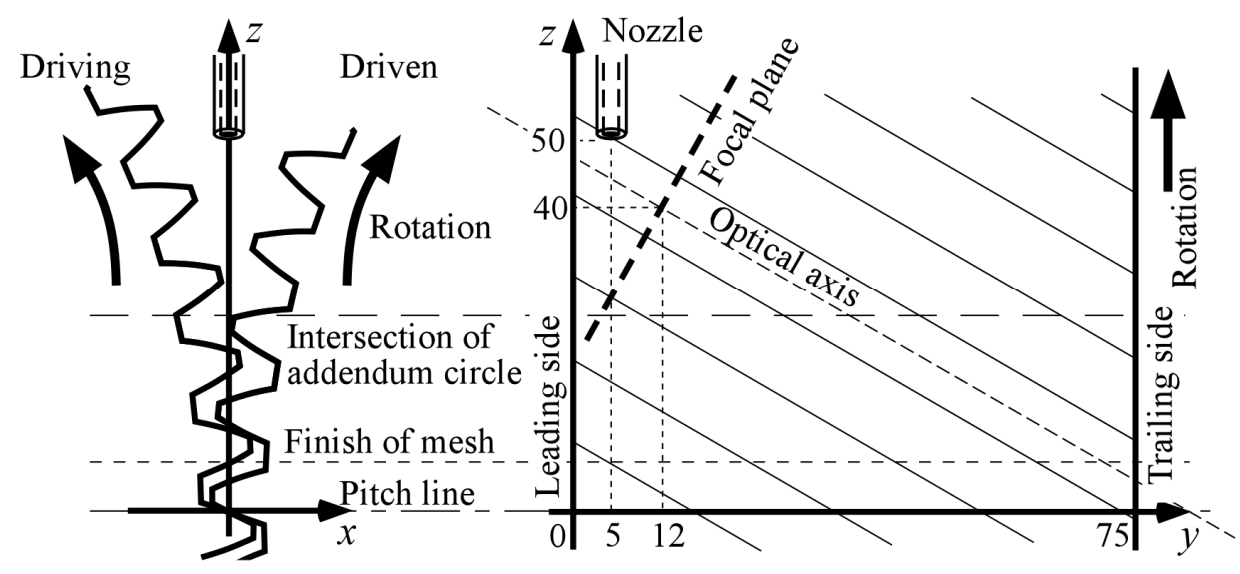

Fig. 6 Geometrical configuration with 3-D coordinates 


\section{$4 \cdot 3$ 粒子の三次元軌跡推定法}

ノズルから射出されて高速度カメラで撮影された粒子軌跡は, PTV (Particle Tracking Velocimetry) ソフトウェア （ディテクト社製 DIPP-Motion Pro2D）によって，撮影フレーム内の二次元座標として数值化した．その座標を 基に, 動画の各フレームに分布する複数の粒子画像を抽出・別途保存し，画像処理によって粒子画像の水平・垂 直軸方向の長さをピクセル数として求めた. そして, 図5の校正結果を参照して, 粒子画像の歪みから基準面位置 に対する相対的な法線方向位置を推定した. 最終的に，PTVソフトウェアによって求められた二次元座標と組み 合わせ，歯車軸に対するカメラ光軸の傾きを補正した上で，4・1節で定義した三次元座標值を求めた.

\section{$4 \cdot 4$ 実験条件}

本論文で示す観察実験結果は, 歯車回転数を 2 ・2節で述べた40rpmと $120 \mathrm{rpm} の 2$ 通りとした上で，ノズル位置を 歯幅方向に変化させて比較した. 歯幅方向に対応寸る $y$ 軸に関するノズル位置の条件は, $y_{N}=5,20,35,45,55,65$,

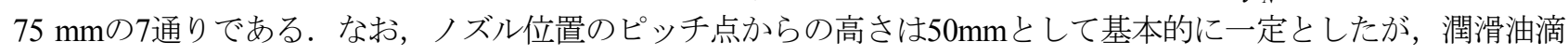
に見立てたステンレス粒子を歯面に到達させることを目的として，40mmに下げた結果もある.

\section{5. 観察結果と考察}

\section{$5 \cdot 1$ 単一方向から観察された粒子の三次元軌跡}

図7は, ノズルから射出された1個の粒子の三次元軌跡を, 前章に述べた手順に従って求めた結果である. 粒子 の三次元軌跡を $x-z$ 平面に投影した図7左側には, 粒子軌跡以外に歯車対の歯先円, 歯元円, ノズル位置が描画 されている. 図7右側の $y-z$ 平面に投影した図には, ピッチ点からの歯先円交点の高さを示寸破線, ノズル位置, 粒子軌跡を撮影したときの基準面位置が示されている.

ノズル位置から引かれた青い実線の軌跡は, 粒子位置が確認できたすべての動画フレーム上で推定された三次 元座標を時系列につなげた線であり，白抜きの青丸は，その軌跡上で $15 \mathrm{~ms}$ 毎に描いた点を示す．青い実線は，基 準面の法線方向に細かく変動しており, 円筒レンズを含む光学系を用いて推定した位置精度の不確定さを表して

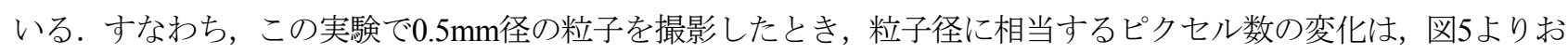
おむね 15 から30程度の範囲であり, それを整数で取り扱っているため, 位置分解能は高いとはいえない. よって, 本論文のこれ以降の粒子軌跡では, 図7の白抜きの青丸に着目して, 粒子軌跡を大局的に捉えることとする.

さらに, 軌跡の下方には赤い点をプロットしている. これは, 粒子がいずれかの歯面に最初に衝突した位置で あり, 撮影した動画より目視で観察・抽出した。本研究では, この位置を潤滑油が付着して冷却が成された場所 とし，ノズルから射出された複数の粒子がそれぞれ最初に歯面に衝突した点の集合が，そのノズル位置から潤滑 できる歯面の領域とした.

図7より，粒子の三次元軌跡が以下のように把握できる，ノズルから射出された粒子は，かみあい部に向かって かみあい終わり側に流されながら降下し, 歯先円交点以下の領域に入ることなく駆動歯車の歯先に接触している. その衝突後, 衝突面であるは寸ば歯車の歯面が，回転方向に対して傾いているため，跳㸚返った粒子の軌跡は水 平に近い角度となってかみあい終わり側に向かい, そのとき被動歯車の歯溝内に留まって移動している. また,
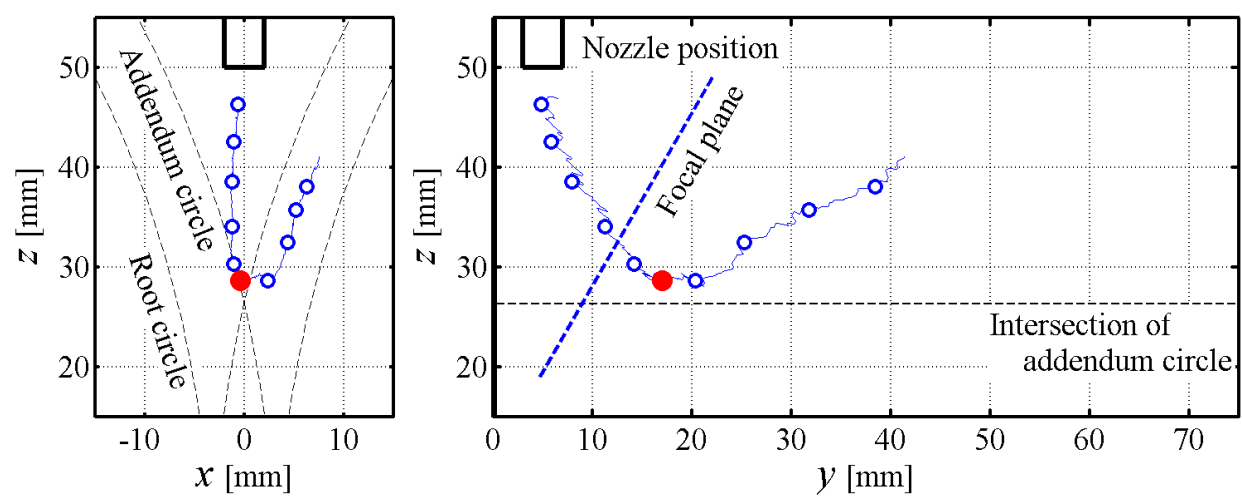

Fig. 7 Visualized 3-D trace of a particle 
青の白丸の間隔から, 衝突後の粒子移動速度が速くなっていることがわかる.

なお，歯面の冷却の観点からは，粒子の歯面への衝突点がピッチ点に近いほど，すみやかな冷却ができる点で 望ましい．また，一般的な減速機を踏まえれば，かみあいに関わる頻度の高い駆動歯車の歯面に衝突するほうが 望ましいと考える.

\section{$5 \cdot 2$ ノズル位置の違いによる粒子軌跡の変化}

本節では, 歯幅方向の各ノズル位置 $y_{N}$ における結果を分類し, その傾向に応じて3つの領域に分けて論じる.

\section{$5 \cdot 2 \cdot 1$ かみあい始め側領域の粒子軌跡}

図8は，歯車回転数が40rpmのときの結果であり，ノズル位置がそれぞれ $y_{N}=5,20,35 \mathrm{~mm}$ である．なお，これ 以降の図では，赤いプロットが示寸粒子の接触点については，塗りつぶした点が駆動歯車への接触を示し，白抜 きの赤丸が被動歯車への接触を示すよう区別している.
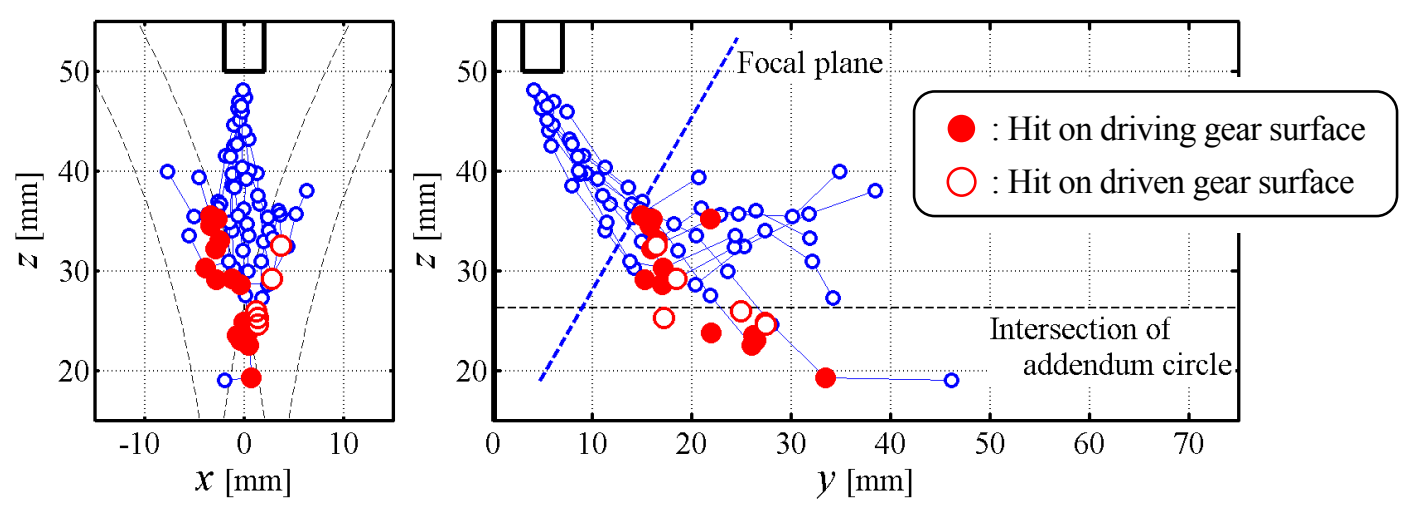

(a) Nozzle position; $y_{N}=5 \mathrm{~mm}$
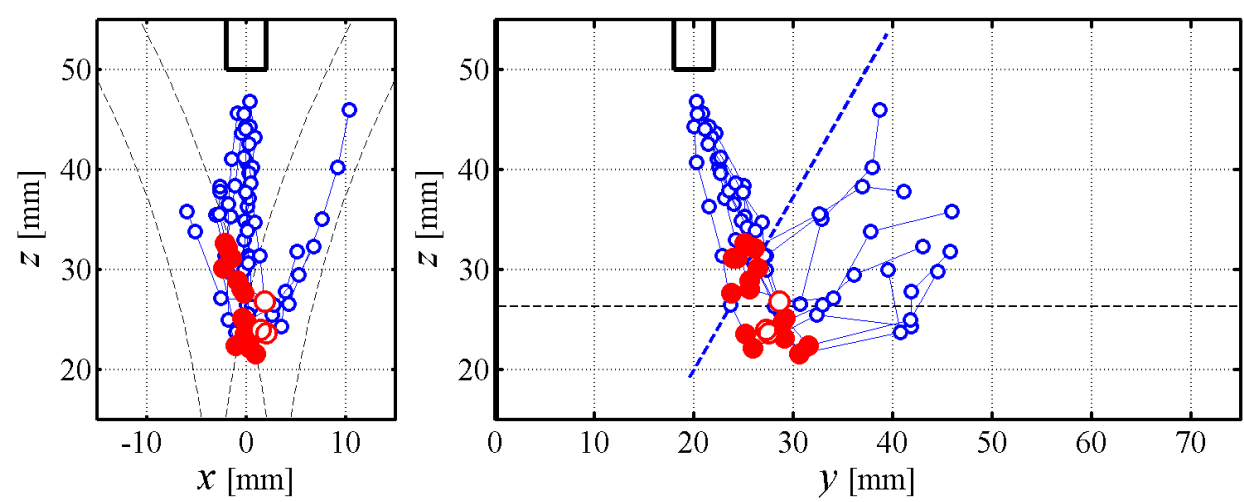

(b) Nozzle position; $y_{N}=20 \mathrm{~mm}$
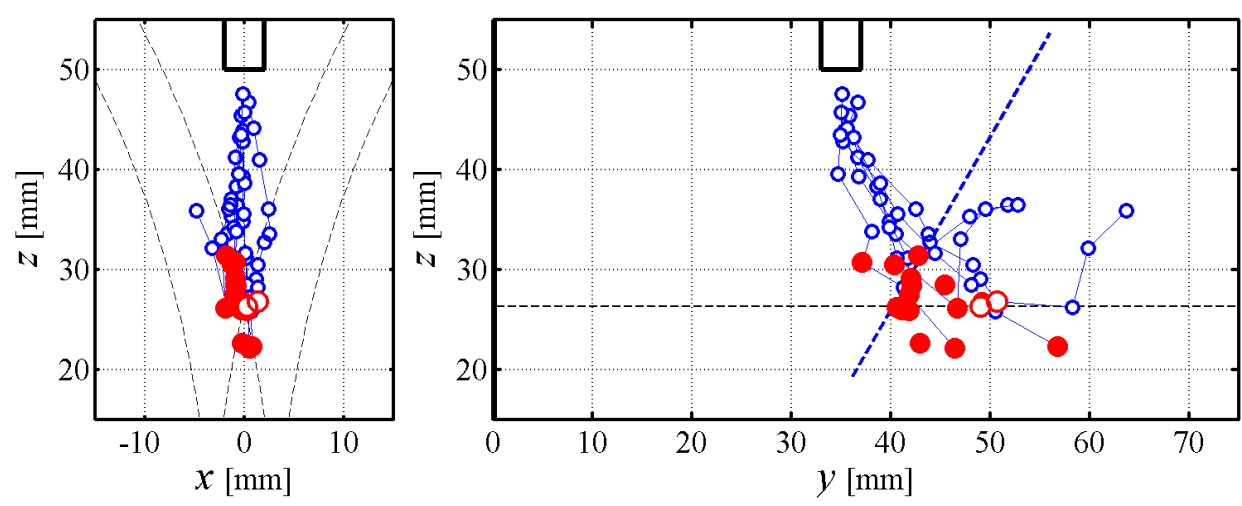

(c) Nozzle position; $y_{N}=35 \mathrm{~mm}$

Fig. 8 Traces of particles at $40 \mathrm{rpm}$ 
すべての結果において，かみあい始め側のノズルから射出された粒子はかみあい終わり側へ流されており，， ズル位置が $y_{N}=5 \mathrm{~mm}$ の結果では顕著である.この領域にそのような空気流れがあることが報告されており ${ }^{(10)}$, 空気中の現象に合致しているといえる.また,ノズル位置の直下が潤滑できるわけではないことを示唆している.

粒子の衝突点については, 歯先円交点以下の領域には到達し難く, $z>30$ といった比較的高い位置で衝突して いることがわかる．これらの位置には，図8(a)〜(c)の $x-z$ 平面の分布より，ノズルからの軌跡が $x$ 軸方向に扇形 に振れて直接向かっていることがわかり，ノズルから射出された粒子が歯車の回転に伴った周辺の流れに引き込 まれていることが予想される. その際, 駆動歯車へ到達している粒子が多いことが認められるが, 確率としてそ のような結果になることは，さらなる実験試行によって確認し，考察する必要があると考えられる.

ノズル位置の条件は同一で, 歯車回転数を120rpmにした結果を図9に示す. 赤いプロットが示す粒子の衝突点 分布は, 図8と比較するとわずかながら上方に移動しているものの, 顕著な差はないといえる. 一方, 粒子軌跡が かみあい終わり側に流される傾向は図8 8 同一であるが，図9(a)に示した $y_{N}=5 \mathrm{~mm}$ の結果においては，軌跡のば らつきが減ってノズル位置から衝突点までより直線的に移動していることがわかる。この現象は，当該領域にか
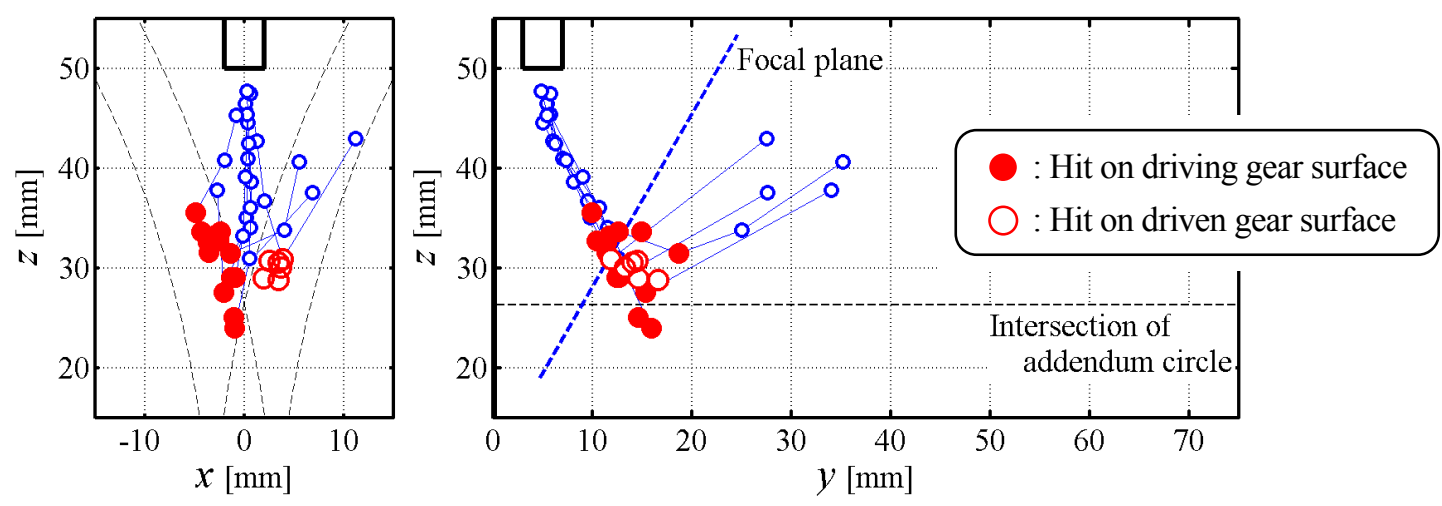

(a) Nozzle position; $y_{N}=5 \mathrm{~mm}$
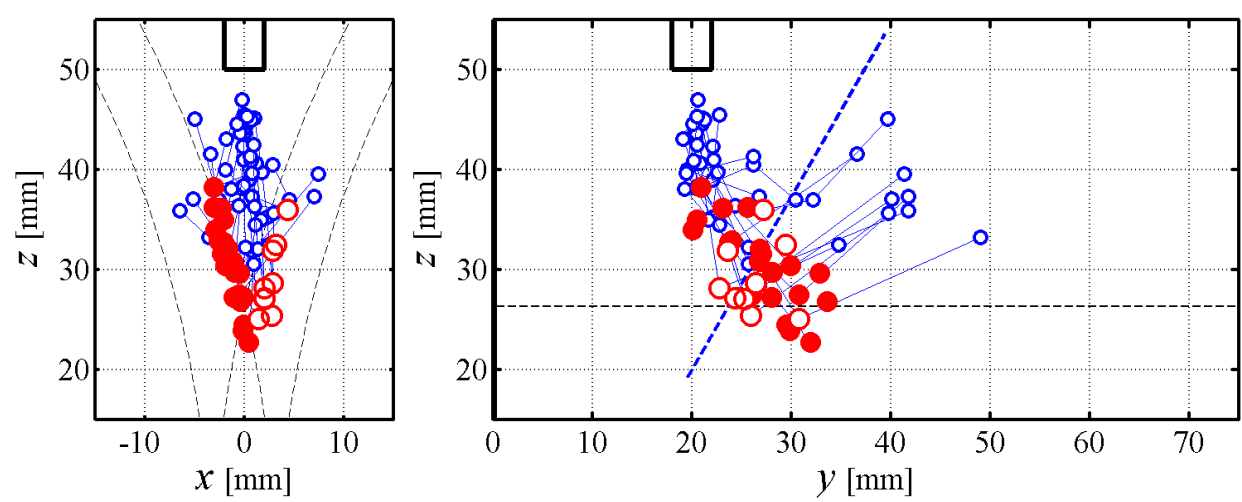

(b) Nozzle position; $y_{N}=20 \mathrm{~mm}$
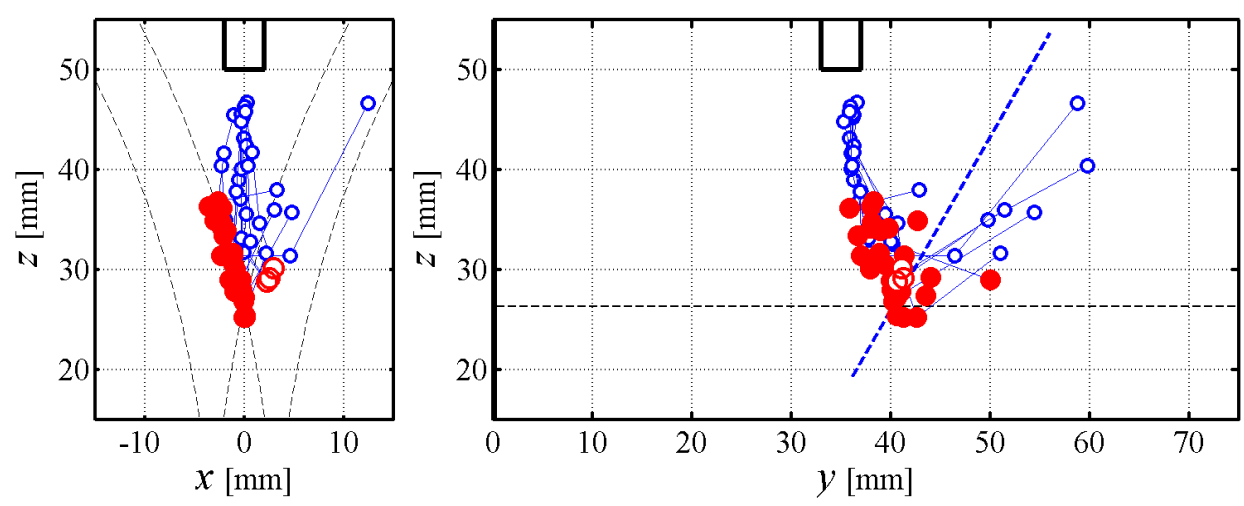

(c) Nozzle position; $y_{N}=35 \mathrm{~mm}$

Fig. 9 Traces of particles at $120 \mathrm{rpm}$ 
みあい部に向かう強い吸入流れがあることが予想され，効率的な潤滑油の供給方法を考慮する上で勘案すべき知 見であるといえる.

\section{$5 \cdot 2 \cdot 2$ かみあいはずれ側の排出流れの影響を受ける軌跡}

図10は，ノズル位置が $y_{N}=45 \mathrm{~mm}$ のときの結果であり，歯車回転数が40rpmと120rpmの場合をそれぞれ示して いる. 図8，9の結果では，赤いプロットが示す粒子の衝突位置の分布が $y-z$ 平面において左上がりの形状であっ たのが, 図10(a)では右上がりの傾向である. 特に右上の衝突点については, ノズルからの粒子軌跡がU字形になっ た上での衝突である. 図10内で，軌跡のひとつを水色の枠内に取り出した。このような $y-z$ 平面におけるU字形 の軌跡は，ノズルから射出された粒子がかみあい部へ下降中に，y=60 mm 付近のかみあいはずれ側に向かう強 い排出流れによって上方に飛ばされた結果であるといえる. その結果として，粒子の衝突点が歯先円交点以下の 領域とならず，冷却のための潤滑が困難な領域であるといえる．なお，この排出流れは，歯幅中央よりもかみあ い終わり側の位置において，歯筋にほぼ垂直に斜め上方に向かう流れとして報告されている(10). 本実験結果の $y-z$ 平面においては，鉛直上向きから右に30度傾いた流れである.

ノズル位置を $y_{N}=55 \mathrm{~mm}$ とした結果を図11に示寸.いずれの歯車回転数の結果においても, 粒子が歯面に衝突 していない. 図11(b)に示した120rpmの結果においては，ノズルからの射出直後に粒子が上方に飛ばされているこ とがわかり，回転数の増加に伴ってより強い排出流れの影響を受けていることがわかる.

さらにノズル位置を $y_{N}=65 \mathrm{~mm}$ とすると, 歯車回転数が $120 \mathrm{rpm}$ では, 図12(b)に示すように射出直後から外向 きに飛ばされている点は図11(b)と同様である。一方，40rpmの場合は，図12(a)に示すように粒子の歯面への衝突 が認められた.しかし, その位置はピッチ点から $z=40 \mathrm{~mm}$ 程度の高さであり, 有効な潤滑とはいい難い. また, 比較的下方に到達した粒子は, 白抜きの赤丸が示すように被動歯車歯面に衝突しているが, その点に至る軌跡は, 水色の枠内に取り出したプロットが示すように，ノズルから射出された粒子が一旦かみあいはずれ側に流された 直後に $x$ 軸の正方向, $y$ 軸の正方向に移動し,$y-z$ 平面上で弓なりに下降して衝突に至っている. これは, か みあい終わり側には吸入流れがあって，粒子がその流れの影響を受けたと考えられる.
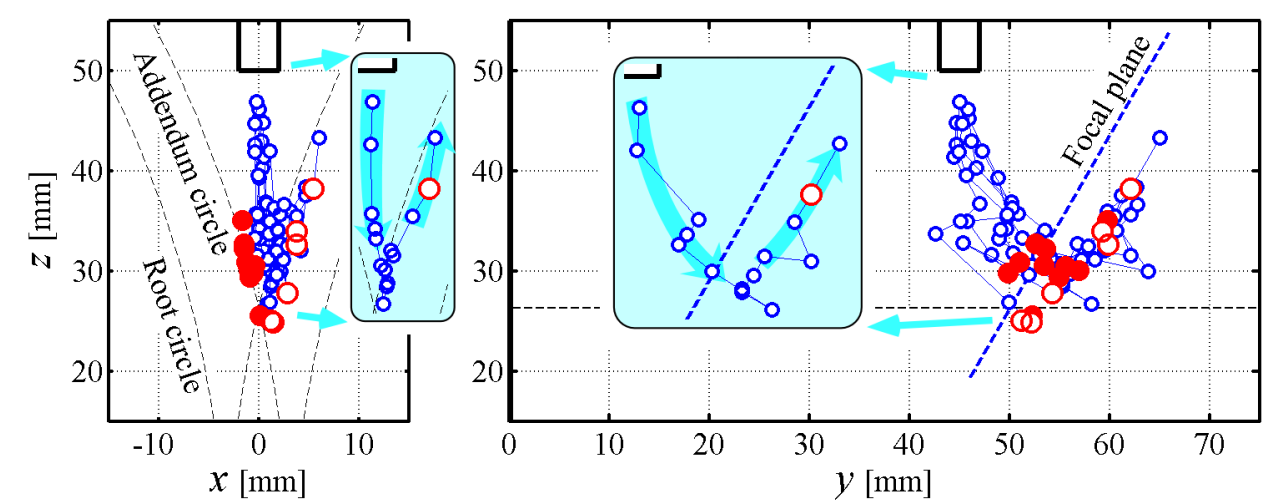

(a) Rotational speed; $40 \mathrm{rpm}$
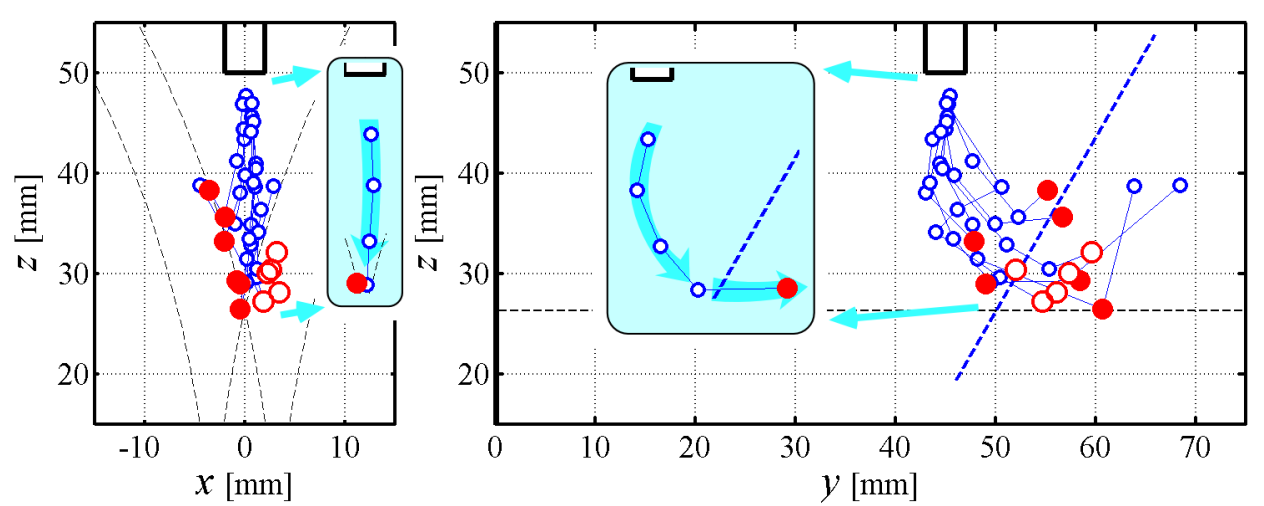

(b) Rotational speed; $120 \mathrm{rpm}$

Fig. 10 Traces of particles at $y_{N}=45 \mathrm{~mm}$ 

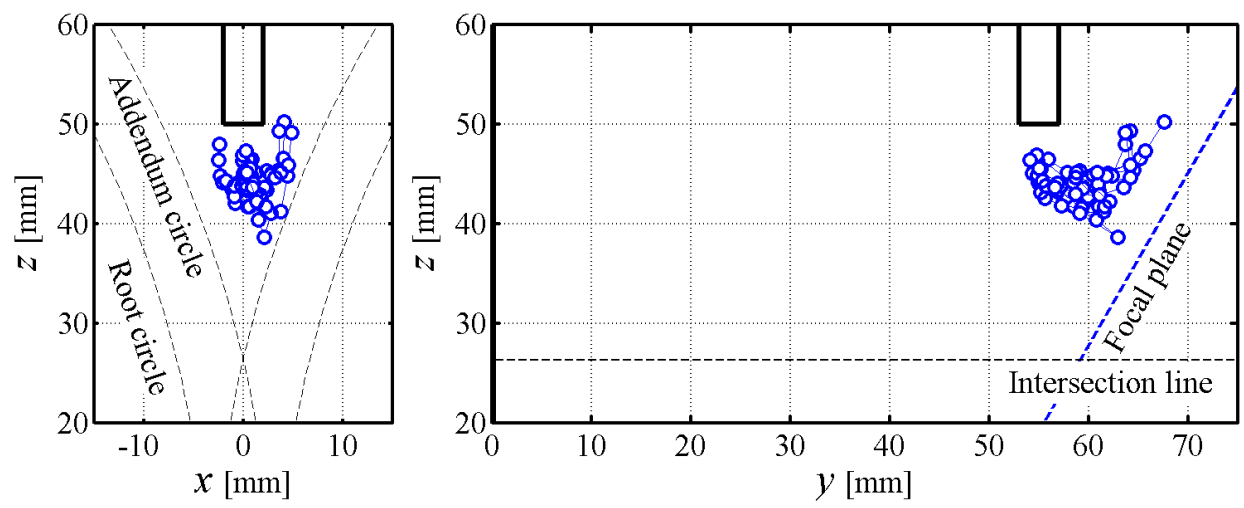

(a) Rotational speed; $40 \mathrm{rpm}$
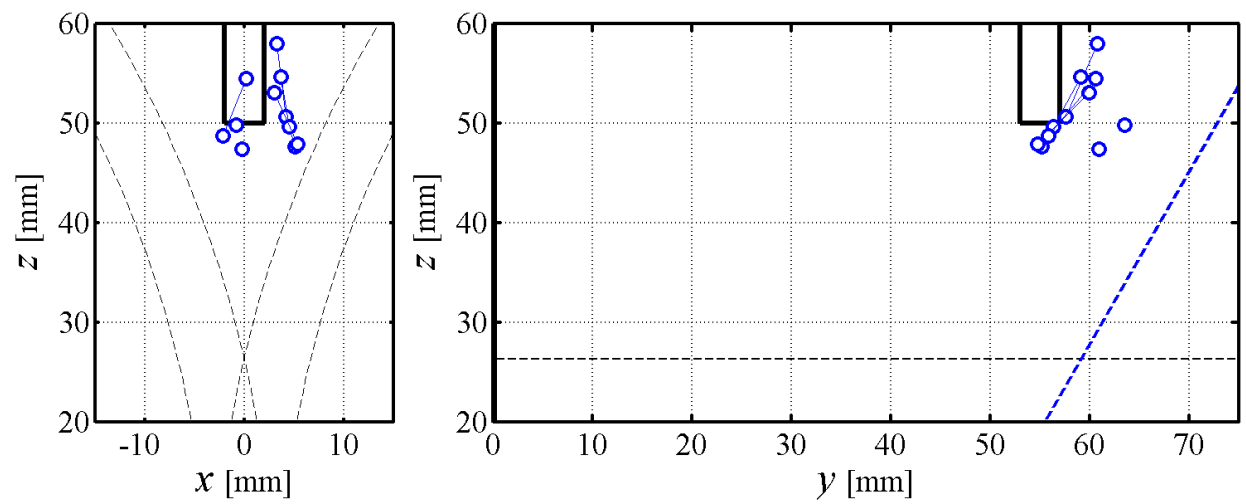

(b) Rotational speed; $120 \mathrm{rpm}$

Fig. 11 Traces of particles at $y_{N}=55 \mathrm{~mm}$
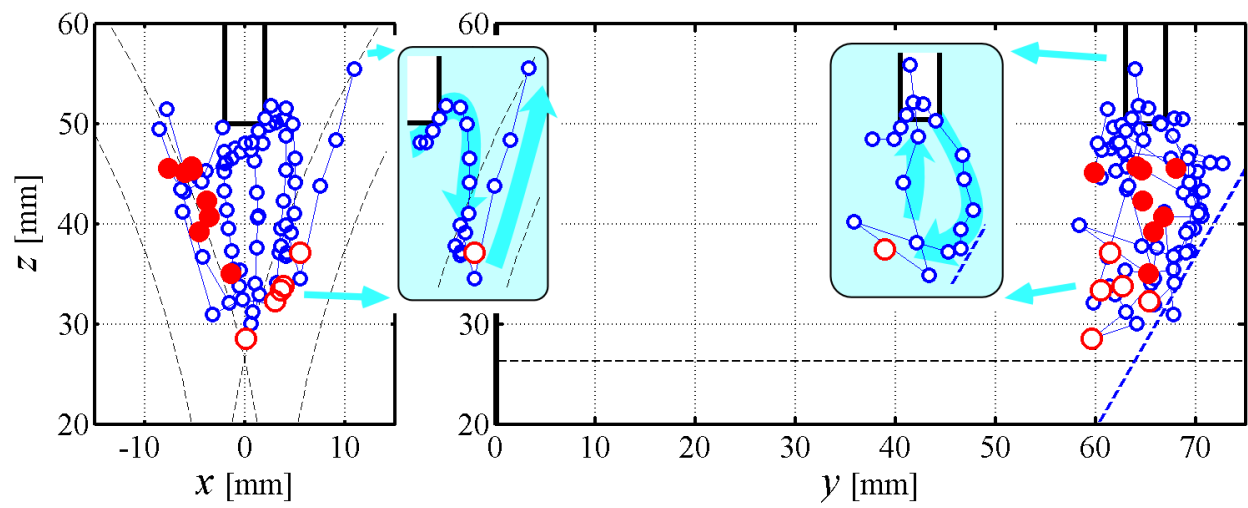

(a) Rotational speed; $40 \mathrm{rpm}$
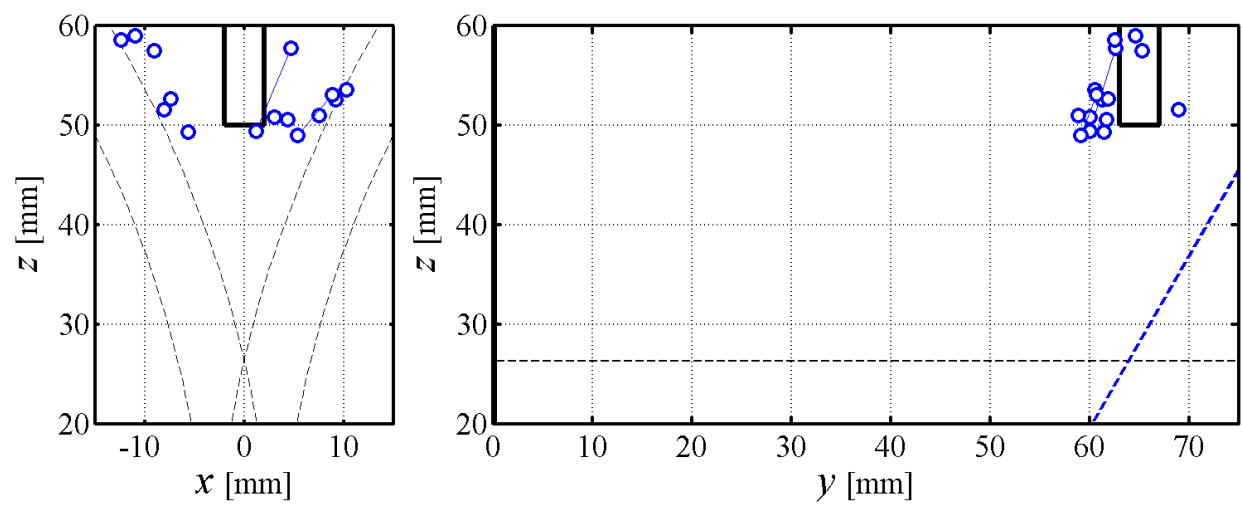

(b) Rotational speed; $120 \mathrm{rpm}$

Fig. 12 Traces of particles at $y_{N}=65 \mathrm{~mm}$ 


\section{$5 \cdot 2 \cdot 3$ かみあい終わり側領域の粒子軌跡}

図13は，ノズル位置を $y_{N}=75 \mathrm{~mm}$ としたときの粒子軌跡の結果である.このノズル位置は，は寸ば歯車対のか みあい終わり側端面上である. 図13(a)に示した歯車回転数が40rpmのときの結果では, 水色の枠内に取り出した プロットが示すように，粒子が歯車の外側に一旦流れてからかみあいはずれ側端面から吸入されている軌跡が確 認できた. また, 赤いプロットが示す粒子が歯面に衝突する位置については, 図12(a)に示した結果よりもよりピッ チ点に近い領域に到達していることがわかる，すなわち，かみあい終わり側には，歯車外部からかみあい部に向 かう吸入流れが存在することが報告されており，本実験で示した粒子の軌跡は，それを効率的な潤滑に利用でき ることを示唆している.

一方，図13(b)の結果では，これまでのノズル位置が $z=50 \mathrm{~mm}$ で一定であったのに対して $z=40 \mathrm{~mm}$ とした. こ れは, $z=50 \mathrm{~mm}$ では粒子の衝突がなかったことから, 潤滑油の確実な供給を確認するために一時的に試行した 結果である.この結果から，ノズル位置をかみあい部に近づけることによって粒子を確実に歯面に到達させるこ とができ，しかも，これまでも結果と比較して，粒子の歯面への衝突位置がより歯元にまで達していることが確 認された.

\section{6. 結 論}

本論文は，はすば歯車のかみあいはずれ側に供給した潤滑油が，どのような軌跡を辿ってどの歯面位置に到達 するのかを実験的に明らかにするために，試験用はすば歯車対を水中で運転し，潤滑油と見立てた微小な金属粒 子を水中に懸濁して，それを三次元的に追跡寸る実験手法を提案した，歯車の運転速度や金属粒子の射出位置を 変化させ, 各条件における粒子軌跡や歯面への到達領域を取りまとめて示した.

本論文の結論は，以下のようにまとめられる.

(1) 粒子軌跡を撮影寸る高速度カメラに円筒レンズを含む光学系を組み合わせ, 非点収差を応用した可視化手法 を提案し，光軸に沿った奥行方向の粒子位置を推定して，粒子の三次元的な挙動を示した.

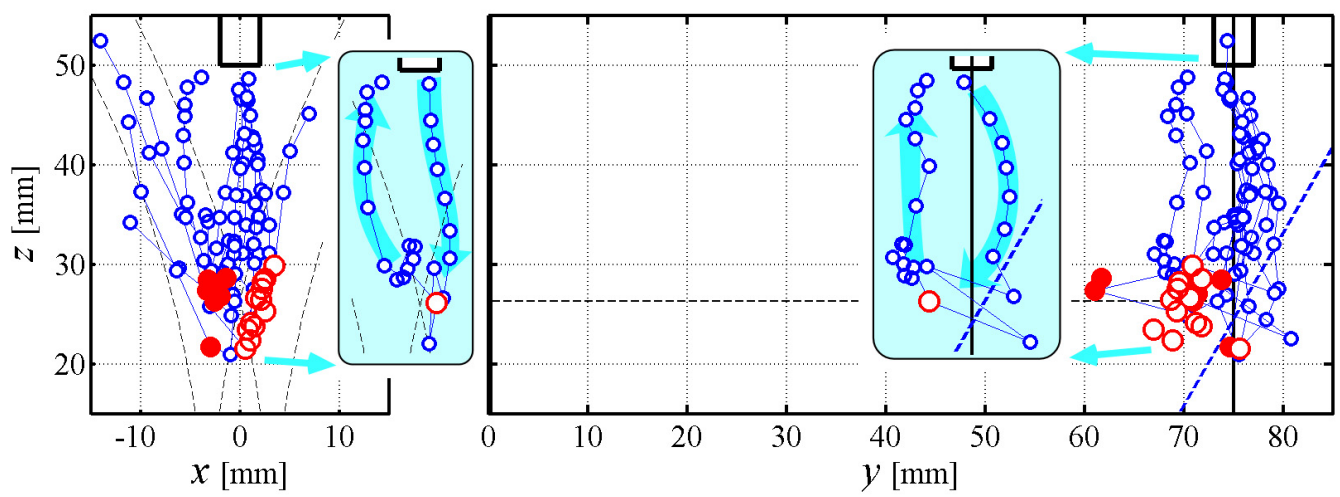

(a) Rotational speed; $40 \mathrm{rpm}$
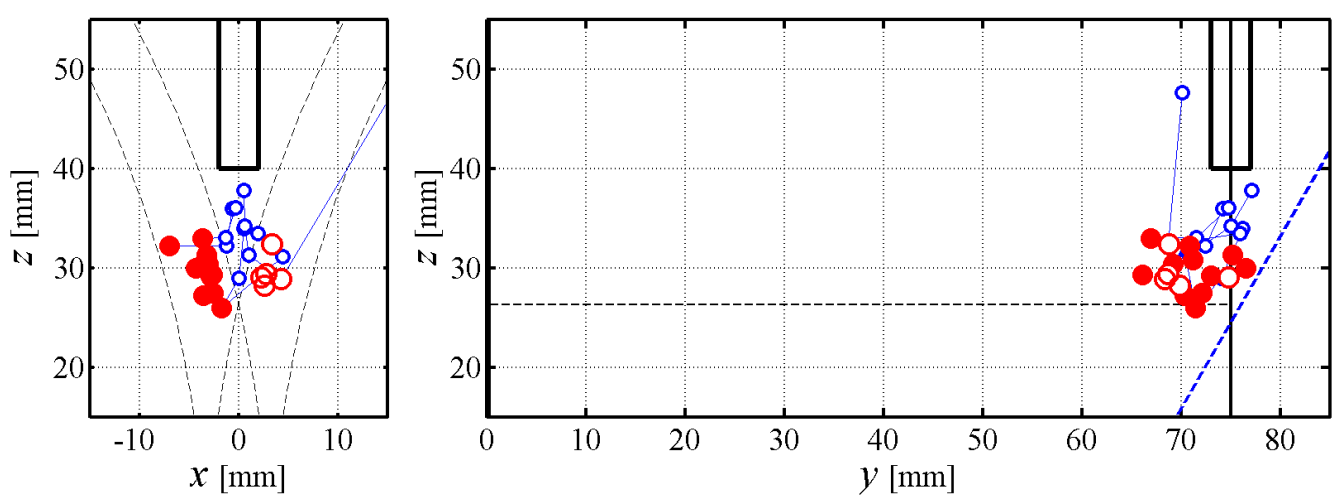

(b) Rotational speed; $120 \mathrm{rpm}$

Fig. 13 Traces of particles at $y_{N}=75 \mathrm{~mm}$ 
(2) 歯幅方向に変化させた各ノズル位置から射出された粒子の挙動は，以下のように分類できることを示した. (a) は寸ば歯車のかみあい始め側領域に射出された粒子は，かみあい終わり側に向かう歯車軸方向の流れに よって，粒子がノズル直下に向かわずにかみあい終わり側に流れて歯面に到達することを示した。

(b) 歯幅中央からややかみあい終わり側の領域では, かみあいはずれ側に向かう強い排出流れによって, 粒子 を歯面に到達させることが困難であることが確認された.

(c) かみあい終わり側に供給された粒子は, かみあい部へ吸入する流れによって, 比較的ピッチ点に近い領域 の歯面に到達することを示した.

(3) 粒子軌跡の挙動は, 潤滑の達成の観点からは, 歯車回転数を3倍に上げてもほぼ同様であることを示した.

本論文で示した結果によれば，粒子は歯面上のほぼピッチ円より歯先側にしか衝突していない，潤滑油で歯面 を十分に冷却するためには，粒子の衝突が歯元に至るような条件を見出すことが必要である.

本論文で示した実験結果は, 当時 東京工業大学 大学院 学生の吉田 拓司 氏, Khaw Ten Kang 氏, 当時 東京 工業大学 精密工学研究所 助教の森 正人 氏らの協力によって得られた。ここに謝意を表す.

\section{文献}

（1）小幡文雄, 若良二, 上原一剛, 小西大二郎, 川村和宏, “PTV 法を用いた平歯車周辺の流動解析”, 日本機械学会 中国四国支部第 39 期総会・講演会講演論文集，No.015-1 (2001)，pp.185-186.

（2）小林俊一，池谷光栄，松本和幸，“遊星歯車装置内部の潤滑油流孔特性”，日本機械学会論文集 C 編，Vol.54， No.508 (1988), pp.3080-3085.

(3) Li, L., Versteeg, H.K., Hargrave, G.K., Potter, T. and Halse, C., "A study of fluid flow of gear lubrication in a spur gear box", Proceedings of VDI Conference Transmission in Vehicles 2008, VDI Berichte 2029 (2008), pp 133-146.

(4) Li, L., Versteeg, H.K., Hargrave, G.K., Potter, T., and Halse, C., "Numerical Investigation on Fluid Flow of Gear Lubrication", SAE International Journal of Fuels and Lubricants, Vol.1, No.1 (2009), pp.1056-1062.

(5) 高橋秀雄, “平歯車により飛沫された流体の挙動”, 日本機械学会第6回機素潤滑設計部門講演会講演論文集, No.06-6 (2006), pp.71-72.

(6) 山田富稔, 三井純一, 藤原一正, 奥井利男, “潤滑油による歯車の冷却”，日本機械学会論文集 C 編，Vol.47, No.419 (1981), pp.901-908.

(7) Akin, L.S., Mross, J.J., and Townsend, D.P., "Study of lubricant jet flow phenomena in spur gears", Journal of Lubrication Technology, Transactions ASME, Vol.97, No.2 (1975), pp.283-288.

（8）藤田公明，小幡文雄，松尾浩平，“平歯車のかみあいにおける潤滑油の挙動一かみ込み側から噴射潤滑寸る場合”, 潤滑, Vol.19, No.6 (1974), pp.437-447.

(9) Houjoh, H., Ohshima, S., Miyata, S., Takimoto, T., and Maenami, K., "Dynamic Behavior of Atmosphere In a Tooth Space of a Spur Gear During Mesh Process From the Viewpoint of Efficient Lubrication”, Proceedings of DETC'00 - 8th International Power Transmission and Gearing Conference, No.PTG-14372 (2000).

(10) Houjoh, H., Ohshima, S., Matsumura, S., and Mori, M., "Flow Visualization of Ambient Air about Mesh Ending Region of Helical Gear Pair by Means of Smoke Wire Method", Proceedings of International Conference on Gears, VDI Berichite, No.1904 (2005), pp.1035-1051.

(11) Houjoh, H., Ohshima, S., Matsumura, S., Yumita, Y., and Itoh, K., "Pressure Measurement of Ambient Air in the Root Space of Helical Gears for the Purpose of Understanding Fluid Flow to Improve Lubrication Efficiency", Proceedings of DETC'03 ASME - 9th International Power Transmission and Gearing Conference, No.48117 (2003).

(12) Mori, M., Houjoh, H., Orimo, K., Kurasawa, S., Matsumura, S., and Ohshima, S., "Three-Dimensional Coordinates Tracking Method of Tracer Particles Using Optical Astigmatism of a Cylindrical Lens", Proceedings of The 9th International Symposium of Fluid Control, Measurement and Vibration, No.167 (2007). 